\title{
EVALUATION OF GENOTYPES ARISING FROM F2 GENERATION SEGREGATIONS IN DWARF X TALL CROSSES OF COCOSNUCIFERA
}

\author{
WMU Fernando and L. Perera ${ }^{1}$
}

\begin{abstract}
Twenty seven $F_{2}$ generation palms belonging to selfed and crossed families of $F_{1}$, palms arising from a cross between dwarf green and Tall in Cocos Nucifera were studied for vegetative, reproductive and yield characters. The objective was to study the segregation patterns of the introgressed characters of the Dwarf $\mathrm{x}$ Tall hybrid in the $\mathrm{F}_{2}$ generation and, to investigate the effects of selfing. An average of four palms were studied in each $F_{2}$ family.

The time takenfor initial flowering was spread in a greater range in $\mathrm{F}_{2}$ families arising from selfed $F_{1}$, compared to $F_{2}$ families originating from crossing two different $F_{1}$ palms. The pollination behaviour of the palms revealed to be segregating in two selfed $F_{2}$ families. Two palms, one in each $F_{2}$ family (selfed $F_{1}$ ) were found to be autogamous with overlapping male and female phases whilst the rest showed allogamy. Recombination of the autogamous nature along with the Tall characters were observed in the $F_{2}$ palms. The results suggest that the genetic control of the pollination behat4our is polygenic and an aggregate of several recessive genes are responsible for the autogamous nature of the palm. Certain genotypes arising from selfed families recorded high husked nut weights (650 - 700 gms) compared to crossed families indicating their resistance to in breeding depression. The possibility of extracting recombined lines with desirable characters in order to improve the Sri Lankan Dwarf $\mathrm{x}$ Tall is also discussed
\end{abstract}

\section{INTRODUCTION}

The identification of the existence of hybrid vigour in inter-varietal crosses of Dwarf $x$ Tall coconut caused a major break through in coconut breeding (Patel 1937). The F, hybrids exhibited precocity in bearing, high nut numbers arid improved nut weights (Bhaskaran arid Leela 1963; Liyanage 1956; Satyabalan et al 1970). Although the hybrids were at an obvious advantage in production potential, their stability mi varying environmental conditions was at a low level. Bavappa et al (1973) reports that the dwarfness of the Dwarf Green is controlled by a heterozygous state and depending upon the heterozygosity of the parents involved in the cross, segregation of dwarfs in the $F_{1}$ population may vary increasing the variability of the $F_{1}$ population. The Sri Lankan experience has shown that the farmer acceptance of Dwarf $\mathrm{x}$ Tall hybrid was not comparable with the levels of the traditional Tall cultivars or the improved talls. (Wickramaratne 1988). The theory of quantitative genetics provide interpretation to the above scenario, that along with the dominant and favourable alleles which bring the maximum heterosis for desirable characters, the recessive and unfavourable genes make their way into the cross thus decreasing its value. Therefore a long term strategy to remedy this situation is to eliminate the tindesirable genes by selfing and selection which would also reduce the variability of the resulting progeny. Before initiating on this task it is important to study the segregation of characters $\mathrm{m}$ selfed generations of $\mathrm{F}_{1}$, 's derived from Dwarf green $x$ Tall crosses and investigate the nature of genetic control. The aim of this paper is therefore to determine the segregation patterns of the characters of economic importance in the $F_{2}$ families derived by selfing of $\mathrm{F}_{1}$ 's of Dwarf green $\mathrm{x}$ Tall crosses. Numerous outbreeding crops such as maize, onion and Brussels sprout have taken the advantage of this method arid significant yield improvements have indeed been made (Simmonds 1979). Not only these annual crops but also certain oil palm populations of exceptional value have been developed from advanced selections at $F_{3}$ and $F_{4}$, generations (Rosenquist 1986).

\footnotetext{
${ }^{1}$ Coconut Research Institute, Lunuwila, Sri Lanka.
} 


\section{MATERIAL AND METHODS}

Selfed and controlled crossed progemies of seven randomly selected Dwarf green $\mathrm{x}$ Tall $\mathrm{F}_{1}$ hybrid palms (Nos 125, 132, 144, 148, 157, 158 and 222) were planted in a fully randomized design at the Bandirippuwa Estate LunuwIla in June 1972 (Anon 1972). Of the $F_{2}$ population planted, seven families were selected for the present study on the basis at least 4-5 individuals of each family with contrasting morphological and reproductive characters were present. The breeding behaviour of each palm was determined by studying the duration. of male and female phases. Height of the trunk of the palm as a measurement of vegetative growth was recorded. Yield data was gathered for 6 picks of 1994 on number of nuts and weight of 3 husked nuts from each pahn. Analyses of variance tests were carried out to detect significant differences between the selfed and crossed families for flowering time, height and Yield data.

\section{RESULTS}

The time taken to flowering of each $\mathrm{F}_{2}$ palm was recorded and the mean flowering time with the range appears in Table 1. The mean flowering time varies from 59 months in the selfed family of 144 to 76 months in the cross $158 \times 125$. No significant differences were present between the selfed and crossed families of individual $F_{1}$ 's for flowering time. The range of flowering time within a family, varied from 11 months to 35 months. The two selfed families had the highest range for flowering time compared to the crossed families. The data on the breeding behaviour revealed that two palms out of the 27 individuals studied, showed overlapping male and female phases indicating autogamy. Both palms arose from selfs of 144 and 157. Data on the duration of male and female phases along with the period of overlap for 5 infloresences opened during the period March to June of the two autogamous pahns are given in Table 2. The mean number of days which the male phase lasted was 18 in both palms but the female phases were of the duration of 4 and 5 days. The whole duration of the female phase overlapped with the male phase in both palms.

The segregation of vegetative and Yield characters of the palms were of great importance. The family means for height of palms, munber of nuts/palm and weight per husked nut appear in Table 3 along with the results of the analyses of variance tests. The amount of total copra was estimated as $32 \%$ of the husked nut weight multiplied by the number of nuts harvested during the period. Significant differences $(\mathrm{P} .=0.05)$ were shown for number of nuts between the selfed and crossed families of palms nos. 157 and 125 and for mean husked nut weight between the selfed and crossed families of palm nos. 125 and 144. The mean height of palms; of the individual families varied from 4.6 meters to 7.3 meters at the age of 21 years from planting. Both extremes were observed in the selfed families of 157 and. 144 respectively. The mean number of nuts for 1994 varied from 66 in the selfed families of 125 and 157 to 115 in the cross $158 \times 125$. The highest husked nut weight was recorded in the selfed family of 144 and it was of a magnitude of three fold of the mean husked nut welght of the cross 157 x 125 . A significant difference in the yield of copra was observed between. the selfed and crossed families of palm no. 144.

A brief description of the segregation and recombination pattern of the identified vegetative, reproductive and yield characters of 5 palms is given in Table 4 . The palm no 4865 arising from the self of 144, shows inbreeding behaviour but has a stature equivalent to a Tall palm and bears nuts weighing 713 gms of mean husked nut which compares well with a standard nut from an elite Tall palm (700 gms) and a yield of 105 nuts/palm/yr. The palm No. 4945 arising from the self of 144 shows typical Tall characters along with a record yield of 164 nuts/palm/year. The palm no 4856 originating from the cross $157 \times 125$ is allogamous, shows a short stature and a reduced nut weight but with a yield of 198 nuts/palm/year. 


\section{DISCUSSION}

The task of describing and using within population diversity and generating further diversity by strategic crossing is longer term and requires the special skills of the Geneticist (Foale 1992). The objectives of this paper are two fold. Firstly to study the patterns of segregation and recombination of characters in the selfed progenies of Dwarf $x$ Tall hybrid crosses and to investigate the consequences of selfing on the characters of economic importance in coconut. Secondly to determine the possibility of developing lines combining the favourable characters of Dwarf and Tall varieties; in order to produce a viable alternative to the hybrid.

The results on the flowering time revealed that the highest variation for flowering time was generated. in the two selfed. families. It is important to note that the progeny of selfed 144 had potential of generating the whole range of variation for flowering time among the 27 individuals studies.

The autogamous nature of the two palms arising from the selfs of 144 and 157 was controlled by an overlap of the female phase lasting for about 4-5 days and. of a male phase of about 18 days. According to Liyanage (1949), the male phase of Sri Lankan Tall and Dwarf varieties lasts for about 18 days but the female phase lasts for 5-7 days in Tall palms and 10-16 days in Dwarf. The inbreeding nature of the present material is assured by following a shorter female phase as of the Tall variety but with an overlap with the male phase.

When considering the vegetative and yield characters of the families indicated in Table 3 , the highest nut number was recorded. for the cross $158 \times 125$ but total yield was not the highest since the nut weight was small in this family. The highest nut weights were recorded in the selfed families of 144 and 125 with 633 gms and 603 gms respectively elucidating the fact that these genotypes are resistant to inbreeding depression. A total copra yield of $21 \mathrm{Kg}$ was obtained by the selfed family of 144 with a superior mean annual nut Yield of 104. On the contrary the selfed family of 157 showed short stature, and low yield. Although there were no significant differences between the selfed and crossed families of palms 125 and 157 for mean copra weight, certain individuals with great potential for improvement were present among these families. The experience in Oil palm (Elaeis guineensis) was similar that extraordinarily superior lines of Oil palm were developed by selfing the crosses of the fruit forms tenera and dura resulting in a combination of favourable characters (Rajanaidu 1986)

The segregation and recombination of the characters at the $\mathrm{F}_{2}$ generation revealed interesting results that stature, flowering time, breeding behaviour and yield segregates independently in the individuals of the families studied. The palm No 4865 arising from the self of 144, combines: the Dwarf character inbreeding, with tall stature, a high husked nut weight equivalent to Tall variety and high nut number. This indicates the fact that inbreeding could be recombined. with other desirable Tall characters. The palm 4856 recombines the short stature and reduced nut weight with allogamy and a very high nut ntunber (198 nuts/palm/year). Considermig the above facts it is possible to genetically tailor the individuals of Dwarf $x$ Tall crosses of coconut by selfing, provided. the level of selfing which would resist in breeding depression is detennined. Developing lines combining the autogamous nature and. early flowering with high yield and. resistance to environmental fluctuations: is indeed advantageous as the genetic stability of the lines are assured by an additive nature of genes rather than. the dominant heterozygous fonn which would segregate, in the next generation as of the present $F_{1}$ hybrids. Furthermore the benefits of this procedure could be harnessed immediately with the success of in-vitro propagation of coconut. 


\section{ACKNOWLEDGEMENT}

The authors wish to thank Dr. M A P Manthriratne former Botanist Coconut Research Institute for initiating this trial and Mr. G K Ekanayake Technical Assistant for his help in data collection.

\section{REFERENCES}

Anonymous 1972. Report of the division of Botany and Plant Breeding. Ceylon Cocon Q. 24: 18-22

Bavappa, K..V.A, Sukumaran, C.K. and Mathew, J. 1973. A Study of F, hybrids of Tall x Dwarf and its bearing on the genetics of dwarfness. J. Plant. Crops 1 (Suppl.): 1-6

Bhaskaran, U.P. and Leela, K. 1963. Hybrid Coconut - Tall x Dwarf - A comparative study with parental types. Agric. Res. J. Kerala 1(2): 6783.

Foale M. A., 1992. Coconut genetic diversity - Present knowledge and future research needs. In: Proc of the IBPGR workshop on Coconut Genetic Resources held at Cipanas Indonesia 8-11 October 1991 International Crop Network Series 8 IBPGR 1992.

Llyanage, D.V. 1949 Preliminary studies on the floral biology of the coconut palm. Trop. Agric. (Ceylon) 105 (4): 171 - 175

Liyanage, D.V. 1956, Intra specific hybrids in Coconuts. Bull. No. 7, Coconut Research Institute, Ceylon.

Patel, J.S. 1937. Coconut breeding. Proc. Assoc. Econ. Biol Coimbatore 5: 1-16

Rajanaidu. N. 1986. The Oil Palm. (Elaeis guineensis) collections; in Africa. In. Proccedings of International Workshop on Oil Palm Germplasm and Utilization 26-27 March 1985, Palm 011 Research Institute Malaysia.

Rosenquist, E. A. 1986. The genetic base of 011 Palm breeding Plantations. Proccedings of International Workshop on Oil Palm Germplasm and Utilization 26-27 March 1985. Palm Oil Research Institute Malaysia.

Satyabalan, K. , and Kunjan, P.V. 1970. Hybrid vigour mi nut and copra characters of coconut hybrids. Indian J. Of Agric. Sci 38: 155 - 160.

Simmonds, N.W., 1979 Principals of Crop Improvernent Longman group London pp 403.

Wickramaratne, M. R. T., 1988. Report on Assessment of experience with new vaneties of coconut. A country report on Sri Lanka on Sri Lankan experience for Asian and Pacific Coconut Community. Coconut Research Institute Sri Lanka. 


\begin{tabular}{|c|c|c|c|c|}
\hline \multicolumn{5}{|c|}{$\begin{array}{l}\text { Table 1. Mean flowering time fo the } F 2 \text { selfed and crossed families and } \\
\text { Range (results of the } F \text { test for selfed vs cross families are given } \\
\text { Where both families are present; } n \text { s }=\text { Pr. of } F>0.05\end{array}$} \\
\hline $\begin{array}{l}\text { F1 palm } \\
\text { No. }\end{array}$ & Cross & $\begin{array}{c}\text { Mean F1 time } \\
\text { (months) }\end{array}$ & $\begin{array}{c}\text { Range } \\
\text { (months) }\end{array}$ & $\begin{array}{c}\text { Pr. Of the } \\
\text { F test }\end{array}$ \\
\hline \multirow[t]{2}{*}{125} & $125 \times 125$ & 73 & $55-84$ & $\mathrm{~ns}$ \\
\hline & $125 \times 144$ & 68 & $56-80$ & $\mathrm{~ns}$ \\
\hline \multirow[t]{2}{*}{144} & $144 \times 144$ & 59 & $45-77$ & \\
\hline & $144 \times 158$ & 65 & $52-79$ & ns \\
\hline \multirow[t]{2}{*}{158} & $158 \times 157$ & 69 & $59-79$ & \\
\hline & $158 \times 125$ & 76 & $71-82$ & - \\
\hline 157 & $157 \times 125$ & 60 & $54-65$ & - \\
\hline
\end{tabular}

\begin{tabular}{|c|c|c|c|c|c|}
\hline \multirow{2}{*}{ Palm of } & \multirow{2}{*}{$\begin{array}{c}\text { Date of } \\
\text { Opening } \\
\text { Of spathe }\end{array}$} & \multicolumn{2}{|c|}{ Male phase } & \multicolumn{2}{|c|}{ Female phase } \\
\hline & & First day & Last days & First day & Last day \\
\hline 4865 & $\begin{array}{c}15 / 2 \\
11 / 3 \\
16 / 4 \\
2 / 5 \\
2 / 6 \\
\end{array}$ & $\begin{array}{c}16 / 2 \\
13 / 3 \\
18 / 4 \\
4 / 5 \\
5 / 6 \\
\end{array}$ & $\begin{array}{c}9 / 3 \\
24 / 3 \\
4 / 5 \\
24 / 5 \\
20 / 6 \\
\end{array}$ & $\begin{array}{c}3 / 3 \\
18 / 3 \\
29 / 4 \\
16 / 5 \\
14 / 6 \\
\end{array}$ & $\begin{array}{c}7 / 3 \\
22 / 3 \\
3 / 5 \\
22 / 5 \\
18.6 \\
\end{array}$ \\
\hline $\begin{array}{l}\text { Mean } \\
\text { (days) }\end{array}$ & & Male phase & 18 & $\begin{array}{c}\text { Female } \\
\text { Phase } \\
\end{array}$ & 5 \\
\hline 4917 & $\begin{array}{c}26 / 2 \\
23 / 3 \\
16 / 4 \\
6 / 5 \\
26 / 5 \\
\end{array}$ & $\begin{array}{c}27 / 2 \\
25 / 3 \\
18 / 4 \\
8 / 5 \\
28 / 5 \\
\end{array}$ & $\begin{array}{c}21 / 3 \\
11 / 4 \\
4 / 5 \\
23 / 5 \\
15 / 6 \\
\end{array}$ & $\begin{array}{c}16 / 3 \\
7 / 4 \\
29 / 4 \\
19 / 5 \\
10 / 6 \\
\end{array}$ & $\begin{array}{c}18 / 3 \\
9 / 4 \\
3 / 5 \\
21 / 5 \\
13 / 6 \\
\end{array}$ \\
\hline $\begin{array}{l}\text { Mean } \\
\text { (days }\end{array}$ & & Male phase & 18 & $\begin{array}{l}\text { Female } \\
\text { Phase }\end{array}$ & 4 \\
\hline
\end{tabular}




\begin{tabular}{|c|c|c|c|c|c|c|c|c|}
\hline \multicolumn{9}{|c|}{$\begin{array}{l}\text { Table 3. Vegetative and yield data of the F2 selfed and crossed families } \\
\text { (significant levels of the } F \text { test are given for selfed vs crossed } \\
\text { families; } *, \operatorname{Pr}=0.05 ; \text { ns }=\text { not significant) }\end{array}$} \\
\hline \multirow[t]{2}{*}{ Cross } & \multicolumn{2}{|c|}{$\begin{array}{l}\text { Mean height } \\
\text { (meters) }\end{array}$} & \multicolumn{2}{|c|}{$\begin{array}{l}\text { Mean no. } \\
\text { Nuts }\end{array}$} & \multicolumn{2}{|c|}{$\begin{array}{l}\text { Mean husked } \\
\text { Nut } \\
\text { wt/nut/gms }\end{array}$} & \multicolumn{2}{|c|}{$\begin{array}{c}\text { Total copra } \\
(\mathrm{kg})\end{array}$} \\
\hline & & Pr. & & Pr. & & $\mathrm{Pr}$. & & Pr. \\
\hline $125 \times 125$ & $\begin{array}{l}5.00 \\
5.65\end{array}$ & $\mathrm{~ns}$ & 66 & $*$ & 603 & $*$ & $\begin{array}{l}12.7 \\
15.9\end{array}$ & $\mathrm{~ns}$ \\
\hline $144 \times 144$ & 7.28 & $\mathrm{~ns}$ & $\begin{array}{l}104 \\
92 \\
\end{array}$ & $\mathrm{~ns}$ & $\begin{array}{r}633 \\
417 \\
\end{array}$ & $*$ & $\begin{array}{l}21.1 \\
12.3 \\
\end{array}$ & $\mathrm{~ns}$ \\
\hline $\begin{array}{l}157 \times 157 \\
157 \times 125\end{array}$ & $\begin{array}{l}4.60 \\
5.41\end{array}$ & $\mathrm{~ns}$ & $\begin{array}{r}66 \\
133\end{array}$ & $*$ & $\begin{array}{l}352 \\
248\end{array}$ & $\mathrm{~ns}$ & $\begin{array}{l}7.4 \\
8.9\end{array}$ & $\mathrm{~ns}$ \\
\hline
\end{tabular}

\begin{tabular}{|c|c|c|c|c|c|c|}
\hline Cross & $\begin{array}{c}\text { Progeny } \\
\text { No. }\end{array}$ & $\begin{array}{l}\text { Time to } \\
\text { Flower }\end{array}$ & $\begin{array}{c}\text { Pollination } \\
\text { Behavior } \\
\text { (months) }\end{array}$ & $\begin{array}{l}\text { Height } \\
(\mathrm{m})\end{array}$ & $\begin{array}{c}\text { No. nuts } \\
1994\end{array}$ & $\begin{array}{c}\text { Husked } \\
\text { Nut wt } \\
\text { (gms) }\end{array}$ \\
\hline $144 \times 144$ & $\begin{array}{l}4945 \\
4865\end{array}$ & $\begin{array}{l}80 \\
52\end{array}$ & $\begin{array}{l}\text { Outbreeding } \\
\text { Inbreeding }\end{array}$ & $\begin{array}{l}7.47 \\
7.70\end{array}$ & $\begin{array}{l}164 \\
105\end{array}$ & $\begin{array}{l}554 \\
713\end{array}$ \\
\hline $157 \times 125$ & $\begin{array}{l}4856 \\
4907\end{array}$ & $\begin{array}{l}63 \\
54\end{array}$ & $\begin{array}{l}\text { Outbreeding } \\
\text { Inbreeding }\end{array}$ & $\begin{array}{l}4.71 \\
6.57\end{array}$ & $\begin{array}{l}198 \\
126\end{array}$ & $\begin{array}{l}271 \\
260\end{array}$ \\
\hline $157 \times 157$ & 4917 & 48 & Inbreeding & 4.66 & 66 & 352 \\
\hline
\end{tabular}

